\title{
Art Music by Caribbean Composers: Dominica
}

\section{Christine Gangelhoff \\ The College of The Bahamas ${ }^{1}$ \\ Cathleen LeGrand \\ Royal Thimphu College, Bhutan}

\section{INTRODUCTION}

Dominica, among the smallest of the Windward Islands, has a very small population. Much of the island is covered in mountain and rain forest. Only small, dispersed pockets of the coastal areas are inhabited. Because the island's terrain prohibits both easy travel and communication across the island, many of these coastal villages have had little contact with one another and, consequently, evolved independently (Guilbault, 1998). These villages, therefore, have a "remarkable degree of local cultural variation" (Bilby, 2005, para. 2).

Spain was the first of the European powers to colonize Dominica. The British and French passed control back and forth several times over the island's colonial history. In 1763, ultimate control was given to the British, who retained their control until its independence in
1979 (Bilby, 2005). The cultures and traditions of both the French and British colonizers have strong influence in Dominica. Both English and a French Creole are widely spoken (Bilby, 2005).

Musical styles in Dominica include folk styles such as bélé; quadrille, influenced by French contradanse; and popular styles such as calypso and the local "cadence-lypso" (Guilbault, 1998). The sounds of bélé music are made with a "one-skinned conical drum and responsorial singing" (Cyrille, 2009, p. 188). Quadrille music is played by bands "that include at least one melodic instrument" (Cyrille, 2009, p. 188). Dominicans refer to such a band as "jing-ping", an accordion (the jing-ping itself), a "frame drum called tanbu bass, a shiyak scraper, and a boom-boom, a four-foot-long end-blown tube traditionally made out of bamboo that is used to play pitches" (Cyrille, 2009, p. 188).

\footnotetext{
${ }^{1}$ Christine Gangelhoff, Assistant Professor, School of Communication and Creative Arts, The College of The Bahamas, P.O. Box N-4912, Nassau, Bahamas; Cathleen LeGrand, Librarian, Royal Thimphu College, Ngabiphu, Thimphu, Bhutan.

Acknowledgments: The authors would like to thank Pearle Christian for her contributions to and assistance with this chapter.

E-mail: cgangelhoff@cob.edu.bs

APA reference: Gangelhoff, C., \& LeGrand, C. (2013). Art music by Caribbean composers: Dominica. The International Journal of Bahamian Studies, 19(2), 44-45. Retrieved from http://journals.sfu.ca/cob/index.php/files/article/view/200/248
} 


\section{REFERENCES}

Bilby, K. (2005). Dominica. In Continuum encyclopedia of popular music of the world: Locations. Retrieved from http://www.credoreference.com/entry/cont pmwl/dominica

Cyrille, D. (2009). Creole quadrilles of Guadeloupe, Dominica, Martinique, and St. Lucia. In P. Manuel (Ed.), Creolizing contradance in the Caribbean (pp. 188208). Philadelphia, PA: Temple University Press.
Guilbault, J. (1998). Dominica. In D. A. Olsen \& D. E. Sheehy (Eds.), Garland encyclopedia of world music, volume 2: South America, Mexico, Central America, and the Caribbean (pp. 840-844). London, England: Routledge.

\section{COMPOSERS}

Lemuel McPherson Christian (1913-2000, born in St. Kitts)

\section{COMPOSITIONS, by composer}

\section{Christian}

The greatest of all builders (1963, Dominica Grammar School song)

Isle of beauty, isle of splendor (1965, Dominica national song, later the national anthem, lyrics by W. O. M. Pond)

\section{RECORDINGS}

\section{Christian}

National anthems of the world, Vol. 3:

Denmark-Grenada [CD]. (2006). Hong Kong:

Marco Polo. Catalogue no. 8.225321

Track 5. Isle of beauty, isle of splendour $(2: 19)$

Track 6. Isle of beauty, isle of splendour [short version] (0:51)

\section{SOUND FILES}

\section{Christian}

Isle of beauty, isle of splendor [MP3 file]. (n.d.). http://www.nationalanthems .info/dm.htm 